\title{
OXFAM GB STATEMENT ON MODERN SLAVERY For the financial year 2016/17
}
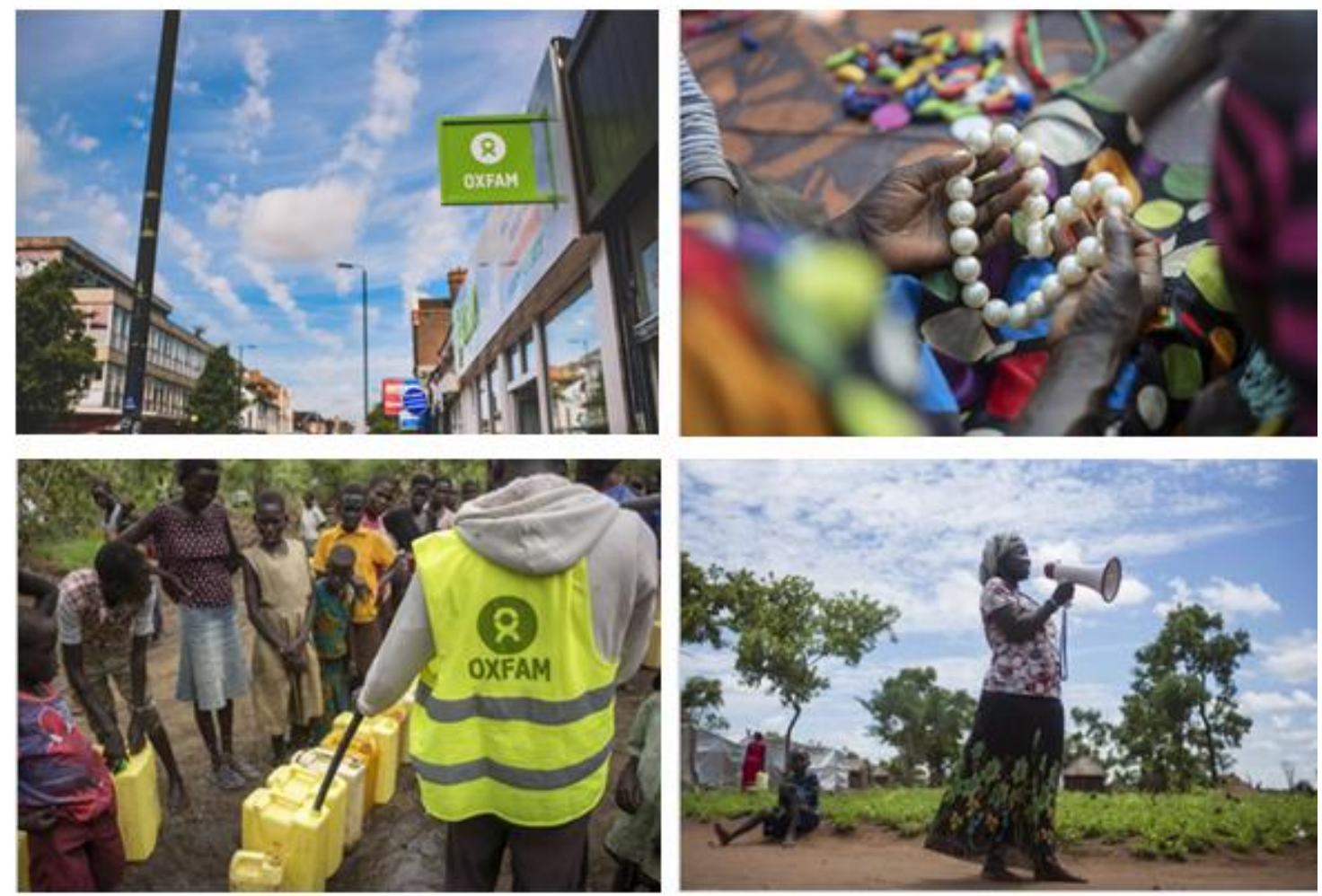

The UK Modern Slavery Act 2015 requires organizations with a turnover of at least $£ 36 \mathrm{~m}$ to make a public statement on steps they are taking to identify and prevent modern slavery in their operations and supply chains. Oxfam GB advocated for this policy development, and this statement relates to steps taken in relation to our own operations and supply chains. Our first statement gave detailed information about our policies and processes in order to demonstrate transparency on this challenging issue and to encourage other companies to be transparent. This statement is an update on progress against the commitments we made in our first statement and shares two case studies of how we work.

SIGNED MARK GOLDRING, CEO, OXFAM GB

This statement can be downloaded from www.policy-practice.oxfam.org.uk 


\section{CONTENTS}

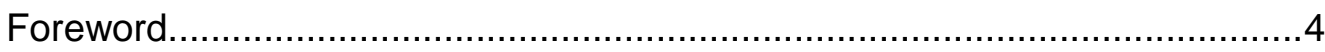

1 Setting the foundations.................................................................6

Case study 1: Oxfam GB's journey to develop an integrated governance

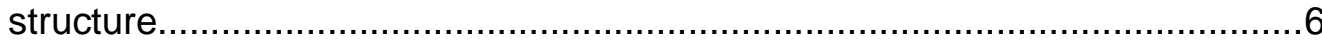

2 Update against commitments made in $2015 / 16$...........................10

3 Oxfam GB's organizational structure and supply chains .............17

How we work as a confederation: the 'One Oxfam' model...........................17

Oxfam GB's staff and contingent (contract)

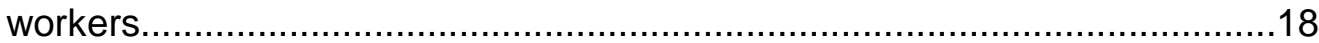

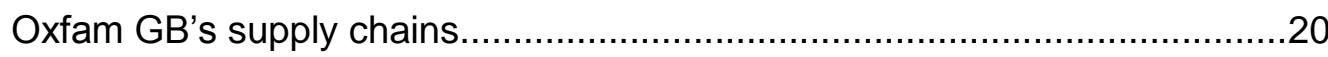

4 Oxfam GB's policies, due diligence processes, risk assessments,

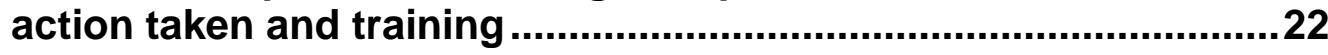

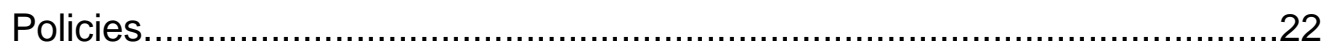

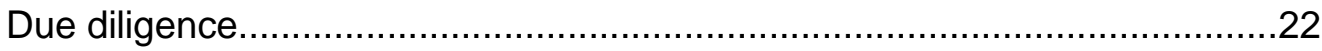

Disclosure of any identified instances of modern slavery and the results of any

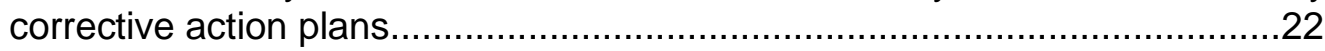

Remedy and compensation provided for labour rights abuses....................23

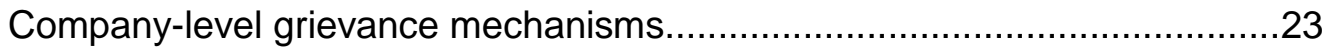

Case Study 2: Our safeguarding work................................................24

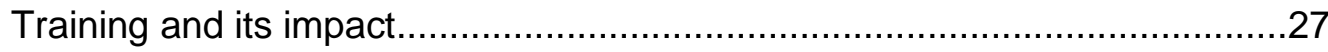

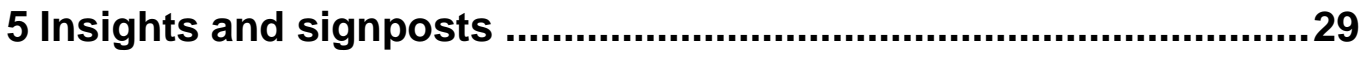

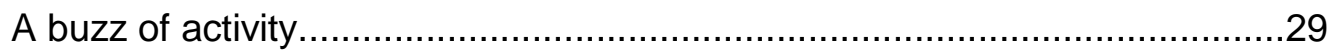

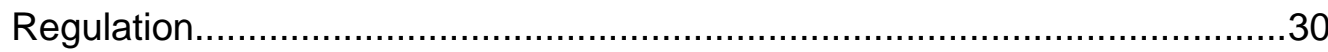

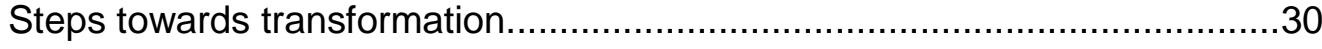

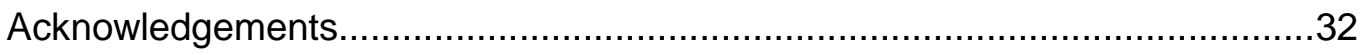

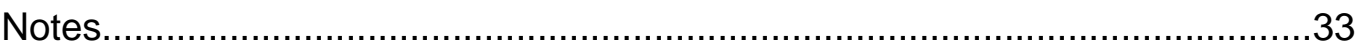




\section{ABBREVIATIONS}

\begin{tabular}{|l|l|}
\hline ACAS & The Advisory Conciliation and Arbitration Service \\
\hline CCS & Crown Commercial Services \\
\hline CL1 & Contingent Labour One \\
\hline CSR & Corporate social responsibility \\
\hline CR & Corporate responsibility \\
\hline DD & Due diligence \\
\hline ETI & Ethical Trading Initiative \\
\hline FTF & Fairtrade Foundation \\
\hline HR & Human resources \\
\hline ILO & International Labour Organization \\
\hline IT & Information technology \\
\hline ITT & Invitation to tender \\
\hline LT & Leadership Team \\
\hline MS & Modern slavery \\
\hline NGO & Non-government organization \\
\hline OJTUS & Oxfam Joint Trade Union Shop \\
\hline OGB & Oxfam Great Britain \\
\hline TAFG & Trustee Audit and Finance Group \\
\hline
\end{tabular}




\section{FOREWORD}

Modern slavery encompasses a spectrum of labour exploitation, ranging from cases where vulnerable workers are mistreated by those with power over them, to human trafficking, the worst forms of child labour and forced sexual exploitation, all of which are among the most horrific abuses a person can experience.

Like other forms of labour exploitation, women are disproportionately affected. An estimated 11.4 million women and girls and 9.5 million men and boys are currently being held in modern slavery worldwide. ${ }^{1}$ Approximately 10.7 million of these people are being exploited within private enterprises in the agriculture, manufacturing, construction, mining and utilities sectors, which between them generate $\$ 43.4 \mathrm{bn}$ annually in illegal profits. $^{2}$

In the UK we have been encouraged to see an increasing number of prosecutions brought under the Modern Slavery Act. ${ }^{3}$ Also, following the conviction of two brothers for trafficking eighteen men to work in a Sports Direct warehouse in Nottinghamshire, ${ }^{4}$ there was a public outcry about Sports Direct's workforce management practices. ${ }^{5}$ This highlighted the need for a culture of proactive prevention of labour exploitation and modern slavery.

To drive change, we have been encouraging companies to adopt a two-pronged strategy: to integrate ethical policies into their core operations and supply chains, and to collaborate with others to address the causes of exploitation and change the playing field so that markets will reward companies for doing the right thing.

In our first report we shared our overall approach to addressing labour standards, along with an overview and some specific examples of the work we are doing. ${ }^{6}$ We shared details about gaps in visibility along our supply chains and limitations in the tools used to identify and address risks to workers.

In this report we highlight two cases studies of how we work and provide updates against the two-year commitments we made in 2016. We continue to be honest about our shortcomings and what we are learning. Our intention is that this will both demonstrate greater transparency and encourage it from others. Transparency is a crucial tool for building an understanding of what works, to identify modern slavery and then respond in the best interests of people living in modern slavery.

The first case study outlines what we have done to transform and integrate Oxfam GB's corporate responsibility governance in order to enable us to effectively address modern slavery issues internally. We have laid what we believe are the foundations needed to enable an organization-wide approach with senior-level support and accountability for addressing this complex issue.

The second case study highlights the work we do to safeguard our programme beneficiaries and our own staff from sexual exploitation and abuse. As we build our organizational understanding about the realities of modern slavery, we recognize that there are important lessons to learn from this robust approach that can apply to both the identification of and response to modern slavery. 
Oxfam GB's central progress this year has been to:

- create an integrated corporate responsibility high-level governance structure which has a director-level steering group and enables visibility of our commitments at trustee level. The Director of Finance has championed this process;

- increase the capacity of its corporate responsibility team to support senior management corporate responsibility leads to manage risks, enable good practice and harmonize our approach;

- provide staff training and communications to ensure that key stakeholders in the organization have a better understanding of our commitment to address this complex and often hidden issue.

This is a challenging process and we still have a lot to learn. We are committed to ensure that our staff can confidently balance decisions between our mission to channel as much of its funds as possible to mitigating and alleviating poverty and suffering, while investing enough to minimize the risk that we are inadvertently supporting modern slavery through our activities. Our new structures should enable us to share learning and improve the ways we identify and respond to modern slavery across the organization over time.

Having invested so much time and effort in ensuring our governance is fit for purpose to tackle modern slavery, we acknowledge that we have not made as much progress as hoped in other areas.

As last year, we have found no instances of modern slavery in our operations or supply chains, but we are more aware of the gaps and limitations in our approach. We continue to target our efforts and collaborate with others so that in future we can be more confident about our how we identify, mitigate and remedy modern slavery in our operations and supply chain.

Oxfam GB continues to advocate for changes in the global trade system that rebalance power, value and risk, so that more people can work their way out of poverty. As part of our commitment to continued labour rights advocacy, this report outlines some of the advocacy we do with companies and investors and we have included a section on insights and signposts to share our learning with others.

We actively seek to learn from others and welcome feedback from those with the expertise that could strengthen our approach, so we have a better idea of what works to mitigate modern slavery and when slavery is identified, to remedy it quickly and effectively.

Mark Goldring, CEO, Oxfam GB, September 2017 
In order to address modern slavery (MS) effectively, there is a need to recognze that the issue is relevant to the organization as a whole (both in supply chains and operations); that decisions need to take account of commercial, operational and human rights priorities; and to ensure there is accountability at senior leadership level. This requires a re-think of how organizations govern their wider corporate responsiblity work; a shift that takes considerable time and effort. The case study below shares the steps Oxfam GB is taking along the way.

\section{CASE STUDY 1: OXFAM GB'S JOURNEY TO DEVELOP AN INTEGRATED GOVERNANCE STRUCTURE}

Our analysis in 2016 showed the relevance of modern slavery, human rights and other corporate responsibility issues to the organization as a whole. Until then, many parts of the organization played a role in addressing human rights; however the standards and approaches were applied within separate departmental frameworks.

Recognizing the need for a strategy that harmonized our approach across its operations and supply chains, we merged the various frameworks and created a new corporate responsibility governance model. The new model was designed to enable:

- a harmonized, integrated approach across our operations and supply chains;

- shared learning between these areas;

- effective oversight and reporting to the directors and trustees;

- efficiency, and to remove duplication of work.

In October 2016, we strengthened the governing body, the Corporate Responsibility Steering Group, so that it had director-level representation from Trading, Fundraising, Campaigns Policy \& Influencing, Finance, International, and Communications. Clear terms of reference were established, clarifying the high-level accountability of directors. It was agreed that the steering group should meet three times a year to shape the Corporate Responsibility Strategy and ensure accountability.

By December, each director had nominated a senior manager to be responsible for driving forward corporate responsibility within their divisions. It was agreed that this model was essential to ensure corporate responsibility and was not managed as an 'add on' but instead integrated into the divisional strategies, and accountability embedded within existing mechanisms.

By January 2017 the steering group had agreed the activities that are within scope for corporate responsibility and the level of ambition in terms of integration. To achieve this, the steering group agreed to co-fund an additional resource based in the central Corporate Responsibility Team to provide support through capacity building, developing systems and reporting.

Key milestones for the new Corporate Responsibility Steering Group were agreed by the end of March 2017, as outlined in Table 1. 
Table 1: Oxfam GB's corporate responsibility (CR) milestones on modern slavery 2017-18

\begin{tabular}{|l|l|}
\hline Target date & Key milestones \\
\hline July 2017 & $\begin{array}{l}\text { Map all relevant themes (e.g. a living wage) in scope for CR by } \\
\text { July 2017 and agree priorities (modern slavery was already } \\
\text { identified as a priority) }\end{array}$ \\
\hline Nov 2017 & $\begin{array}{l}\text { Divisional CR leads to map all relevant areas of the organization } \\
\text { to the priority themes and agree priority actions to take forward. } \\
\text { This step to be informed by our existing MS commitments and } \\
\text { form the MS strategy to ensure an integrated approach }\end{array}$ \\
\hline Nov 2017 & $\begin{array}{l}\text { Divisional CR leads to create divisional accountability } \\
\text { mechanisms and reporting by November } 2017\end{array}$ \\
\hline Nov 2017 & Reporting to trustees agreed by November 2017 \\
\hline March 2018 & CR policy to be written by March 2018 \\
\hline
\end{tabular}

Oxfam GB's International Division manages operations and supply chains from its country and regional offices. This division has delayed its $\mathrm{CR}$ work for one year due to significant governance changes between Oxfam GB and affiliates, including change in executive power in some cases (see section 3 ).

The central Corporate Responsibility Team drove the process. The team's purpose (as defined in 2016 when it was created by merging other roles involved ethical assessments) is to create a harmonized approach to corporate responsibility and provide specialist advice to enable good practice and manage risks.

Oxfam's staff work to alleviate poverty and suffering. Because modern slavery is often hidden and complex, there is a need to help teams understand that their work may nonetheless be inadvertently contributing modern slavery. This is particularly difficult for teams to accept, given the nature of their work. Once the risk is recognized, teams face the difficult task of balancing the need to deliver their work while managing resources or time needed to mitigate modern slavery. For example, in our work in developing countries we often need to buy items quickly from local markets within countries that have poor labour rights regulations and illegal activity. The dilemma for Oxfam is how to manage the risk of modern slavery without hindering its mission-critical work.

To facilitate the shift in governance, the central Corporate Responsibility Team:

- had support from the Director of Finance, who agreed to chair the steering group. This support was a result of the Director of Finance being involved in the sign-off process for the Modern Slavery Statement which raised her awareness of the crossorganizational relevance of this work;

- drew on the CEO's communication about the importance of addressing modern slavery (both within our previous statement and in his updates to trustees and other stakeholders) to emphasize the need for an effective, integrated approach to address modern slavery;

- shared the findings from our previous Modern Slavery Statement with key internal stakeholders, ${ }^{7}$ stressing that there can be a risk of modern slavery in divisions where it had not previously been considered;

- emphasized that modern slavery is a hidden and complex issue and therefore not immediately evident across the organization. This provoked an interest in understanding the issue and how it can be addressed. 
- emphasized that appropriate governance will enable the owners of the modern slavery commitments (operational teams) to have organizational support in delivering them;

- emphasized the benefits of the divisions shaping the Corporate Responsibility Strategy, as it will dovetail with their work more effectively. Members of our Trading Division who have worked to this model for several years shared examples of the benefits of this approach.

'Oxfam's devolved approach to CR gives our buyers the ownership they need to manage ethical and environmental issues in a holistic way which complements the commercial process rather than hindering it."

Sophie Brill, Buying Manager, Trading

The central Corporate Responsibility Team recruited a trade union specialist on a oneyear contract to build the capacity of the team, increase their knowledge and shape their longer term approach to supporting freedom of association and collective bargaining. The links between addressing modern slavery and enabling freedom of association became clearer and will be integrated into the Corporate Responsibility Strategy.

The central team has worked with the new governance body to start the process of understanding modern slavery in order to develop appropriate approaches to addressing potential risks. This significant change will enable a long-term strategic approach, which is essential to address a widespread and complex issue such a modern slavery.

Figure 1: Oxfam GB's corporate responsibility governance structure

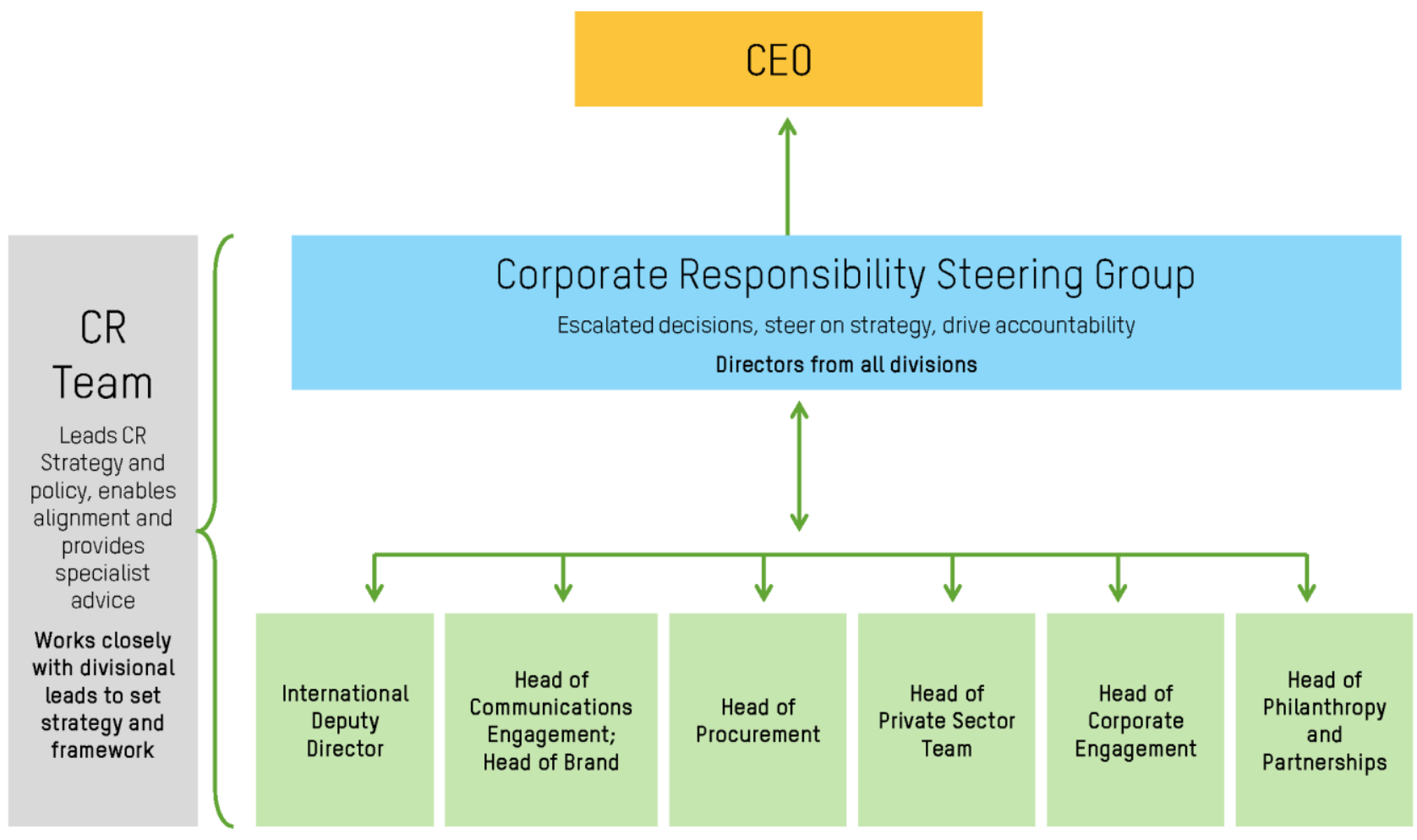


Table 2: Roles and responsibilities within the governance structure

\begin{tabular}{|c|c|c|}
\hline Function & Role & Responsibility \\
\hline $\begin{array}{l}\text { Corporate Responsibility } \\
\text { Steering Group }\end{array}$ & $\begin{array}{l}\text { Directors from all divisions } \\
\text { To champion the vision for } \\
\text { corporate responsibility at } \\
\text { Oxfam, providing steer on } \\
\text { the CR strategy, and to hold } \\
\text { divisions to account }\end{array}$ & $\begin{array}{l}\text { - Sets organizational CR } \\
\text { standard, signs off policy and } \\
\text { ensures accountability with } \\
\text { operational teams } \\
\text { - Point of escalation } \\
\text { - Meets three times a year, and } \\
\text { flexibly for escalation }\end{array}$ \\
\hline $\begin{array}{l}\text { Corporate Responsibility } \\
\text { Divisional Leads }\end{array}$ & $\begin{array}{l}\text { Accountable for the } \\
\text { implementation of the CR } \\
\text { strategy within specific } \\
\text { operational areas }\end{array}$ & $\begin{array}{l}\text { - Feeds into the overall } \\
\text { organizational CR strategy and } \\
\text { position, working with the CR } \\
\text { team } \\
\text { - Sets, implements and reports on } \\
\text { team/departmental strategy in } \\
\text { line with overarching CR strategy } \\
\text { - Ensures appropriate } \\
\text { representation at the CR } \\
\text { Committee fortnightly meetings }\end{array}$ \\
\hline $\begin{array}{l}\text { Corporate Responsibility } \\
\text { Team }\end{array}$ & $\begin{array}{l}\text { To shape and drive the } \\
\text { Corporate Responsibility } \\
\text { Strategy; to work closely } \\
\text { with operational teams to } \\
\text { provide specialist advice } \\
\text { on policies, positions and } \\
\text { processes to enable } \\
\text { alignment with Oxfam's CR } \\
\text { strategy. }\end{array}$ & $\begin{array}{l}\text { - Writes CR strategy/framework, } \\
\text { policy positions and terms of } \\
\text { reference in consultation with } \\
\text { CR leads } \\
\text { - Drives harmonization on CR } \\
\text { and related policies/positions } \\
\text { across the business } \\
\text { - Facilitates escalation to the } \\
\text { Steering Group as appropriate }\end{array}$ \\
\hline
\end{tabular}




\section{UPDATE AGAINST COMMITMENTS MADE IN 2015/16}

Last year we identified some gaps in our approach to identifying and addressing the risk of modern slavery in our operations and supply chains. As a result, we made a number of commitments to be met over a two-year period. In this section we provide an update against those commitments.

We prioritized cross-organizational corporate responsibility governance and accountability in order to mitigate the risk of modern slavery across our operations and in its supply chains. This took longer than planned, which resulted in delays in making progress against other commitments. These will therefore be the focus of our work during the second year of the two-year commitments timeline.

\begin{tabular}{|c|c|c|}
\hline Commitment & Date due & Update \\
\hline $\begin{array}{l}1.1 \text { Embedded organization- } \\
\text { wide understanding and } \\
\text { responsibility for modern } \\
\text { slavery }\end{array}$ & $\begin{array}{l}\text { March } \\
2018\end{array}$ & $\begin{array}{l}\text { Progressing well } \\
\text { To enable this, we significantly changed our } \\
\text { corporate responsibility governance model to ensure } \\
\text { organization-wide director-level oversight and } \\
\text { accountability; reporting to our Trustees on work to } \\
\text { address corporate responsibility within our own } \\
\text { activities. Modern slavery has been identified as a } \\
\text { priority area. See case study } 1 \text { for more information. } \\
\text { We consulted the CEO of Anti-Slavery International, } \\
\text { who suggested we build on the established good } \\
\text { practice of our prevention of sexual exploitation and } \\
\text { abuse (PSEA) team to inform how we would respond } \\
\text { to cases of modern slavery. See case study } 2 \text { in } \\
\text { section } 4 \text { for more information. } \\
\text { Oxfam GB's Private Sector team recruited an } \\
\text { additional post focused on labour rights, to } \\
\text { strengthen our work to tackle the root causes of in- } \\
\text { work poverty and labour exploitation in global supply } \\
\text { chains, looking particularly at the role of investors, } \\
\text { governments and companies. }\end{array}$ \\
\hline $\begin{array}{l}\text { 1.2 Develop organization-wide } \\
\text { Modern Slavery Strategy } \\
\text { involving accountable } \\
\text { operational and procurement } \\
\text { senior managers. This strategy } \\
\text { will be directly linked to our work } \\
\text { on wages and freedom of } \\
\text { association. The strategy will be } \\
\text { directly informed by the due } \\
\text { diligence commitments identified } \\
\text { below. }\end{array}$ & Dec 2017 & $\begin{array}{l}\text { In progress - delayed } \\
\text { The Modern Slavery Strategy is in progress, but a } \\
\text { few months delayed. We have learned through } \\
\text { integrating our governance structure that it is best to } \\
\text { include our Modern Slavery Strategy as part of our } \\
\text { wider Human Rights Strategy. The additional full-time } \\
\text { post in the central Corporate Responsibility Team } \\
\text { was recruited as planned in FY } 2017 / 18 \text { and will lead } \\
\text { this work. } \\
\text { The trade union specialist contracted for FY } 2016 / 17 \\
\text { worked with the CR team to enable a better } \\
\text { understanding of how to integrate freedom of } \\
\text { association into our work on Modern Slavery } \\
\text { Strategy. } \\
\text { This commitment relates to our UK-managed supply } \\
\text { chains and operations. See commitment } 1.3 \text { for our } \\
\text { work at country programme level. }\end{array}$ \\
\hline
\end{tabular}




\begin{tabular}{|c|c|c|}
\hline $\begin{array}{l}1.3 \text { Include International } \\
\text { Programme work in the scope } \\
\text { of our Modern Slavery } \\
\text { Strategy and reporting. By } \\
\text { November } 2017 \text { we will have } \\
\text { defined a process for assessing } \\
\text { risks related to modern slavery } \\
\text { in Oxfam GB's programmes at } \\
\text { country level. }\end{array}$ & Nov 2017 & $\begin{array}{l}\text { Delayed by } 1 \text { year } \\
\text { Oxfam GB's Deputy International Director met with } \\
\text { the CEO of Anti-Slavery International in order to } \\
\text { inform our approach. } \\
\text { Given the significant structural changes planned } \\
\text { during } 2017 \text { for our International Programme (see the } \\
\text { changes outlined in the section 'how we work as One } \\
\text { Oxfam' in section } 3 \text { for more information), it was } \\
\text { agreed that we need to delay our work on modern } \\
\text { slavery in our International Programme for one year. } \\
\text { This includes operations and supply chains managed } \\
\text { at a country level. }\end{array}$ \\
\hline $\begin{array}{l}\text { 1.4 Revise current due } \\
\text { diligence frameworks } \\
\text { informed by the Ethical } \\
\text { Trading Initiative (ETI) model } \\
\text { for Central Procurement, } \\
\text { Humanitarian Procurement and } \\
\text { New Products teams. }\end{array}$ & $\begin{array}{l}\text { June } \\
2017\end{array}$ & $\begin{array}{l}\text { Slow progress } \\
\text { This commitment requires organization-wide } \\
\text { engagement. We have set up the right governance } \\
\text { model to deliver this commitment, but are delayed in } \\
\text { revising our framework. } \\
\text { When we started to work through the ETI Due } \\
\text { Diligence Framework we identified the need for a } \\
\text { collaborative approach to interpreting and } \\
\text { implementing the framework. } \\
\text { We have advocated collaborative work on shaping a } \\
\text { shared risk assessment framework, drawing from } \\
\text { credible trade union and civil society information on } \\
\text { the right to organize; collective bargaining density in } \\
\text { countries and sectors; minimum wages relative to } \\
\text { poverty lines, etc., to inform our approach. A } \\
\text { collaborative approach would reduce unnecessary } \\
\text { duplication of work and ensure that organizations are } \\
\text { working from similar analysis frameworks from which } \\
\text { they can prioritize their work on modern slavery. } \\
\text { Progress has been slow. } \\
\text { We recognize that this commitment is delayed and } \\
\text { have set a new date for March } 2017\end{array}$ \\
\hline $\begin{array}{l}\text { 1.5. Information gathering on } \\
\text { good practice policies in } \\
2016 / 17 \text { to inform the } 2017 / 18 \\
\text { update of our Corporate } \\
\text { Responsibility Policy }\end{array}$ & $\begin{array}{l}\text { March } \\
2018\end{array}$ & $\begin{array}{l}\text { We have identified that good practice includes } \\
\text { proactive prevention of modern slavery, i.e. zero } \\
\text { tolerance to inaction on modern slavery. For } \\
\text { example, if workers are paying recruitment fees, } \\
\text { companies should demonstrate zero tolerance } \\
\text { towards suppliers/employers doing nothing to rectify } \\
\text { that situation, since no worker should pay to get a } \\
\text { job. We will continue to seek good practice examples } \\
\text { to inform our policy, which is due to be updated by } \\
\text { March } 2018 \text {. }\end{array}$ \\
\hline
\end{tabular}


Table 4: Commitment 2 - Training and communications to embed understanding of modern slavery

\begin{tabular}{|c|c|c|}
\hline Commitment & Date due & Update \\
\hline $\begin{array}{l}\text { 2.1. Organization-wide } \\
\text { communication on the } \\
\text { importance of addressing } \\
\text { modern slavery and what } \\
\text { Oxfam GB's commitments and } \\
\text { actions are. }\end{array}$ & $\begin{array}{l}\text { Sept } \\
2016- \\
\text { June } \\
2017 \\
\text { (phase 1) }\end{array}$ & $\begin{array}{l}\text { Phase } 1 \text { completed } \\
\text { Our commitment to address modern slavery has } \\
\text { been communicated through a number of channels } \\
\text { including: } \\
\text { - CEO end-of-year letter to staff, which highlighted } \\
\text { our work on modern slavery as one of two key } \\
\text { operational examples; } \\
\text { - CEO report to trustees; } \\
\text { - A summary of our Modern Slavery Statement was } \\
\text { shared with Oxfam's Trustee and Finance Auditor } \\
\text { Group, along with a link to the full document; } \\
\text { - Key points from the Modern Slavery Statement } \\
\text { were presented to Oxfam affiliates with trading } \\
\text { activities at the Trading Director's meeting; } \\
\text { - To staff through internal bulletins; } \\
\text { - To procurement staff through training - see } \\
\text { commitment 2.2. }\end{array}$ \\
\hline $\begin{array}{l}\text { 2.2. Follow-up training for all } \\
\text { procurement teams and } \\
\text { relevant stakeholders on } \\
\text { Oxfam GB's programme to } \\
\text { address modern slavery }\end{array}$ & $\begin{array}{l}\text { Dec } 2016 \\
\text { (phase 1) }\end{array}$ & $\begin{array}{l}\text { Phase } 1 \text { completed } \\
\text { Oxfam's New Product (retail), Central Procurement } \\
\text { and Humanitarian Procurement Teams (UK-based } \\
\text { teams) participated in a four-hour training session on } \\
\text { labour and environmental standards in our supply } \\
\text { chains. A significant portion of the training focussed } \\
\text { on labour rights and stressed the relationship } \\
\text { between modern slavery, wages and freedom of } \\
\text { association. See section } 4 \text { for analysis of the impact } \\
\text { of training. }\end{array}$ \\
\hline $\begin{array}{l}\text { 2.3. Our recruitment training } \\
\text { will include content about } \\
\text { modern slavery }\end{array}$ & $\begin{array}{l}\text { March } \\
2017\end{array}$ & $\begin{array}{l}\text { Completed } \\
\text { In November 2016, a section on modern slavery was } \\
\text { added to the recruitment training course. Fifty people } \\
\text { have attended recruitment training during the period } \\
\text { November } 16 \text { to March } 17 \text {. }\end{array}$ \\
\hline $\begin{array}{l}\text { 2.4. Identify appropriate } \\
\text { ways to support suppliers }\end{array}$ & On-going & $\begin{array}{l}\text { Progressing } \\
\text { Key retail suppliers were invited to join the above- } \\
\text { mentioned four-hour training session. We also had } \\
\text { targeted meetings with key suppliers. An analysis of } \\
\text { surveys undertaken both pre- and post-training show } \\
\text { the impact of the training. See section } 4 \text { for more } \\
\text { information. } \\
\text { We have also provided direct advice to suppliers on } \\
\text { their Modern Slavery Statements and agreed to } \\
\text { review two of our supplier's Ethical Trade Strategies } \\
\text { later in } 2017 \text {. } \\
\text { We appreciate this is just the beginning of our efforts } \\
\text { to support suppliers effectively, and we will continue to } \\
\text { develop this as part of our Modern Slavery Strategy, } \\
\text { which we aim to complete by March } 2018 \text {. }\end{array}$ \\
\hline
\end{tabular}


Table 5: Commitment 3 - Internal monitoring and evaluation

\begin{tabular}{|l|l|l|}
\hline Commitment & Date due & Update \\
\hline $\begin{array}{l}\text { 3.1. Develop indicators for } \\
\text { measuring the Procurement } \\
\text { Team's understanding of } \\
\text { modern slavery and the } \\
\text { impact of training }\end{array}$ & $\begin{array}{l}\text { Early } \\
2017 \\
\text { (Phase 1) }\end{array}$ & $\begin{array}{l}\text { Phase 1 complete } \\
\text { We conducted modern slavery training with both the } \\
\text { UK-based Procurement and the New Products (retail) } \\
\text { buying teams and used pre- and post-training surveys } \\
\text { to measure their understanding. See section 4 for more } \\
\text { information on the impact of training. }\end{array}$ \\
\hline $\begin{array}{l}\text { 3.2. Seek good practice } \\
\text { examples }\end{array}$ & On-going & $\begin{array}{l}\text { To date, we have identified a critical incident } \\
\text { approach as best practice for learning. See case } \\
\text { study 2 for more information on this. }\end{array}$ \\
\hline $\begin{array}{l}\text { 3.3. Report risk indicators } \\
\text { related to modern slavery in } \\
\text { supply chains }\end{array}$ & $\begin{array}{l}\text { June } \\
\text { Delayed } \\
\text { This will be completed as part of our Due Diligence } \\
\text { Framework. See Commitment 1.4. }\end{array}$ \\
\hline
\end{tabular}

Table 6: Commitment 4 - Address any risks of modern slavery: actions by department

\begin{tabular}{|c|c|c|}
\hline Commitment & Date due & Update \\
\hline $\begin{array}{l}\text { 4.1. Contingent labour: } \\
\text { increase the due diligence } \\
\text { process for Category } 3 \\
\text { agencies }^{8} \text { to ensure a } \\
\text { consistent standard across all } \\
\text { three categories }\end{array}$ & $\begin{array}{l}\text { June } \\
2017\end{array}$ & $\begin{array}{l}\text { Progressing slowly } \\
\text { We have identified that Oxfam uses an agency to } \\
\text { hire temporary workers for one area of work that we } \\
\text { had not identified last year. This agency's hiring } \\
\text { practices will be reviewed by August } 2017 \text {. As annual } \\
\text { spend is under £6k, and this area was identified after } \\
\text { the reporting period, we do not have data on the } \\
\text { number of individuals hired for the FY. We will } \\
\text { require this of the agency moving forward. } \\
\text { Our retail team has moved to a warehouse staff } \\
\text { model that significantly reduces its need for agency } \\
\text { workers by hiring } 4 \text { new staff who can cover all } \\
\text { 'business as usual' volume. } \\
\text { Our procurement approach was to extend the crown } \\
\text { commercial service sourcing framework to include } \\
\text { Category } 3 \text { agencies. However for commercial } \\
\text { reasons this has not been possible. Therefore, short- } \\
\text { term checks have been made as mentioned in } \\
\text { section } 3 \text {, and the Procurement Team is reviewing } \\
\text { options to ensure a more consistent approach. } \\
\text { NB. This commitment applies to our contingent } \\
\text { labour in the UK. Please see commitment } 4.6 \text { for an } \\
\text { update on how we are addressing contingent labour } \\
\text { at a country programme level. }\end{array}$ \\
\hline $\begin{array}{l}\text { 4.2. On-site contracted } \\
\text { services: strengthen our due } \\
\text { diligence regarding agency } \\
\text { hiring processes for Oxfam } \\
\text { House on-site services }\end{array}$ & $\begin{array}{l}\text { March } \\
2017 \\
\text { (phase 1) } \\
\text { March } \\
2018 \\
\text { (phase 2) }\end{array}$ & $\begin{array}{l}\text { Phase } 1 \text { Progressing slowly } \\
\text { We have identified additional due diligence checks } \\
\text { that we need to do with our onsite service providers. } \\
\text { These checks are in progress but slightly delayed. }\end{array}$ \\
\hline
\end{tabular}




\begin{tabular}{|c|c|c|}
\hline $\begin{array}{l}\text { 4.3. Promotional items: } \\
\text { develop appropriate beyond } \\
\text { audit approaches with the } \\
\text { supplier }\end{array}$ & $\begin{array}{l}\text { Nov } 2017 \\
\text { (phase 1) }\end{array}$ & $\begin{array}{l}\text { Progressing } \\
\text { This project is moving forward. We have worked } \\
\text { closely with our promotional items supplier and are in } \\
\text { the final stages of agreeing the Memorandum of } \\
\text { Understanding with a UK trade union that will deliver } \\
\text { training to our suppliers on the benefits of freedom of } \\
\text { association. } \\
\text { We participated in the promotional items supplier's } \\
\text { workshop for its own suppliers, attended by four of } \\
\text { their suppliers, and then signed up in principle to } \\
\text { joining this project. }\end{array}$ \\
\hline $\begin{array}{l}\text { 4.4. Retail products: focus on } \\
\text { agency hiring practices with } \\
\text { three key sites }\end{array}$ & On-going & $\begin{array}{l}\text { Some progress } \\
\text { Our buying team met with the suppliers to emphasize } \\
\text { our concern regarding contingent labour, as a } \\
\text { contingent workforce is more vulnerable to modern } \\
\text { slavery practices. } \\
\text { One supplier owns the site that supplies Oxfam GB. } \\
\text { They are using Stronger Together's resources and } \\
\text { training to inform their approach to modern slavery. } \\
\text { The supplier confirmed that agency workers have the } \\
\text { same rights as permanent workers (the supplier } \\
\text { relies on audits to confirm this), and the supplier has } \\
\text { met with the recruitment agencies for their sites and } \\
\text { confirmed that no fees are charged for agency } \\
\text { workers. All independent audits include agency } \\
\text { workers within their scope. We have informed the } \\
\text { supplier that once our Modern Slavery Strategy is } \\
\text { developed, our requirements will expand in scope. } \\
\text { The second supplier is reviewing whether they will } \\
\text { include forced labour supplement checks when } \\
\text { conducting audits at their site. Movement has been } \\
\text { slow on this and we have stressed that once our } \\
\text { Modern Slavery Strategy is developed our } \\
\text { requirements will increase. The site has been } \\
\text { working with the supplier for over } 20 \text { years, and } \\
\text { previously commissioned Impactt Ltd. to conduct a } \\
\text { transparency assessment of their site. } \\
\text { The third site is also owned by the supplier. The } \\
\text { supplier has reviewed the policies and processes of } \\
\text { their agency labour provider who is a registered } \\
\text { business partner of Stronger Together and uses their } \\
\text { tools to inform their processes for recruitment, } \\
\text { training and ongoing due diligence. }\end{array}$ \\
\hline $\begin{array}{l}\text { 4.5. We will provide training } \\
\text { to the suppliers that } \\
\text { identified forced labour risks } \\
\text { in late } 2016\end{array}$ & & $\begin{array}{l}\text { Some progress } \\
\text { Last year we reported that three supplier sites had } \\
\text { contractual clauses requiring overtime from their } \\
\text { workers. We reported on the steps taken and made a } \\
\text { commitment to provide training to the suppliers to } \\
\text { increase their understanding of the issue. Over the } \\
\text { last financial year, two of the three suppliers attended } \\
\text { our half-day training, which included a substantial } \\
\text { section on labour rights and modern slavery. The } \\
\text { third supplier was unable to attend but was sent a } \\
\text { copy of the materials. All three suppliers are } \\
\text { developing their ethical sourcing strategies or } \\
\text { statements, which they are due to share with Oxfam } \\
\text { during } 2017-18 \text {. }\end{array}$ \\
\hline
\end{tabular}




\begin{tabular}{|l|l|}
\hline $\begin{array}{l}\text { 4.6. We will work with our } \\
\text { International Programme } \\
\text { country teams to confirm } \\
\text { that we do not use agency } \\
\text { staff }\end{array}$ & $\begin{array}{l}\text { Some progress } \\
\text { Oxfam GB is in the process of becoming One Oxfam } \\
\text { with 20 Oxfam affiliates across } 70 \text { countries. As a } \\
\text { result, this commitment has been delayed by one } \\
\text { year but will apply to all country programmes in the } \\
\text { confederation, rather than just those that OGB is } \\
\text { supporting. Please see section } 3 \text { for more } \\
\text { information. }\end{array}$ \\
\hline
\end{tabular}

\section{Table 7: Commitment 5 - Monitoring and evaluation reporting and communication}

\begin{tabular}{|c|c|c|}
\hline Commitment & Date due & Update \\
\hline $\begin{array}{l}\text { 5.1. We will develop key } \\
\text { performance indicators } \\
\text { (KPIs) to enable us to } \\
\text { measure progress against } \\
\text { our internal improvement } \\
\text { plans and report on progress } \\
\text { in our } 2016 / 17 \text { Modern Slavery } \\
\text { Statement. } \\
\text { We have included the risk of } \\
\text { modern slavery existing in our } \\
\text { supply chains in the } \\
\text { procurement risk register for } \\
2016 / 17 \text {. }\end{array}$ & & $\begin{array}{l}\text { Some progress } \\
\text { We have a central commitments table that teams are } \\
\text { responsible for updating with their progress. Progress } \\
\text { against this commitment is monitored by the central } \\
\text { Corporate Responsibility Team. The KPIs will be } \\
\text { strengthened once the due diligence framework and } \\
\text { reporting are complete. } \\
\text { Modern slavery was added to Oxfam's procurement } \\
\text { risk register to ensure that it is visible to the Trustee } \\
\text { Audit and Finance Group. }\end{array}$ \\
\hline $\begin{array}{l}\text { 5.2. We will develop and } \\
\text { report against KPIs to the } \\
\text { Corporate Responsibility } \\
\text { Steering Group on the } \\
\text { progress we are making } \\
\text { against commitments set in } \\
\text { this statement every six } \\
\text { months from December } 2016, \\
\text { and we will include a section } \\
\text { on modern slavery in Oxfam } \\
\text { GB's Annual Report and } \\
\text { Accounts. }\end{array}$ & & $\begin{array}{l}\text { Some progress } \\
\text { The Corporate Responsibility Steering Group was in } \\
\text { a transitional stage in November as the new } \\
\text { members and governance were being finalized, so } \\
\text { headlines on the progress against the Modern } \\
\text { Slavery Commitments was only shared with the Chair } \\
\text { (Director of Finance) in November } 2016 \text {. The KPIs } \\
\text { will be strengthened once the due diligence } \\
\text { framework and reporting are complete. } \\
\text { Oxfam's commitment to address modern slavery is } \\
\text { referenced in its Annual Report and Accounts. }\end{array}$ \\
\hline $\begin{array}{l}\text { 5.3. Externally, we will } \\
\text { continue to undertake } \\
\text { advocacy on labour rights in } \\
\text { global supply chains, and will } \\
\text { ensure that this incorporates } \\
\text { our learning and activities } \\
\text { relating to modern slavery. }\end{array}$ & & $\begin{array}{l}\text { Through our 'critical friend' advocacy relationships } \\
\text { with companies, we have continued to recommend } \\
\text { that they integrate their human rights policies into } \\
\text { their core business practices, drawing on our } \\
\text { experience. } \\
\text { We have increased the amount of policy and } \\
\text { advocacy initiatives we undertake on modern slavery } \\
\text { in } 2017 \text {. For instance, we agreed to partner with } \\
\text { ShareAction on the Workforce Disclosure Initiative } \\
\text { (WDI), an initiative to achieve greater disclosure } \\
\text { about the workforces in listed companies' operations } \\
\text { and key supply chains. }{ }^{9} \text { The initiative is funded by } \\
\text { DFID, and the Secretary of State included the WDI in } \\
\text { its portfolio of initiatives to tackle modern slavery, }\end{array}$ \\
\hline
\end{tabular}




\begin{tabular}{|l|l|}
\hline \multicolumn{1}{|l|}{} & describing it as 'a new partnership with ShareAction \\
and Oxfam, which brings together some of the \\
world's biggest institutional investors to encourage \\
the companies they invest in to seek out and tackle \\
modern slavery within their supply chains.' \\
Oxfam co-developed the survey that will be used in \\
this first pilot year by 79 investors, who between \\
them manage nearly $\$ 8$ trillion of assets under \\
management. The survey questionnaire includes \\
questions on the company's governance of workforce \\
management in its operations and key supply chains; \\
on the recruitment practices of its critical suppliers \\
(use of agencies, payment of recruitment fees, \\
retention of identity documents) disaggregated by \\
gender; asks whether the company has carried out a \\
human rights impact assessment, and if so, did this \\
explicitly consider risks related to gender and/or \\
vulnerable workers, and requests information on \\
grievance management and worker representation. \\
Oxfam also commissioned research in 2017 into in- \\
work poverty and egregious labour rights abuses in a \\
range of food commodity sectors, and is actively \\
considering options for public awareness-raising \\
activities in a range of countries in the global North \\
and global South.
\end{tabular}




\section{OXFAM GB'S ORGANIZATIONAL STRUCTURE AND SUPPLY CHAINS}

In the 2016 statement, we provided a comprehensive overview of Oxfam GB's organizational structure. Oxfam GB's UK-based activities have not changed considerably; therefore please see Oxfam GB's Annual Report and Accounts for more information.

However, the way that we work with our country programmes is undergoing a significant confederation-wide change process. We include a description of the changes below, as they have affected the timing for delivering on our commitment to address modern slavery risks in our operations and supply chains that are managed at a country level.

\section{HOW WE WORK AS A CONFEDERATION: THE ‘ONE OXFAM' MODEL}

Throughout the 2016/17 financial year we significantly reshaped the way that we work as part of the confederation of 20 Oxfam affiliates, to ensure that we make the most of our collective influence and effectiveness through closer collaboration. We call this significant organizational change programme 'Oxfam 2020'. The drivers for the changes that we are making are to ensure that we:

- are more rooted in the countries where we work;

- are stronger in the way we influence global, regional and national change to eliminate poverty and injustice;

- are simpler in how we work to reduce cost and complexity and increase efficiencies;

- have better ability to share knowledge, evidence and expertise to deliver high-quality programmes.

The Oxfam 2020 changes will ensure that, by March 2018 (and much earlier in many countries), we have aligned all Oxfam activities in a country under the leadership and accountability of one Oxfam Country Director. That Country Director will be responsible for delivering a shared One Oxfam Country Strategy using one Oxfam affiliate's systems and processes and will be managed by one overarching Oxfam International Programmes Director. This contrasts with the previous arrangements, where, prior to the change programme, there were a number of Oxfam Country Directors in each country who were employed by individual Oxfam affiliates to manage each Oxfam affiliate's programme investments. This resulted in a multiplicity of systems and reporting tools being used by different Oxfam affiliates in any one country.

Some Oxfam affiliates will provide the underpinning systems and processes to enable our country offices to operate effectively (for example, being the legally registered entity in-country, employing all staff and providing HR, IT, finance, logistics, support systems, policies and procedures). 
In the 2016/17 financial year, considerable steps were made in making the One Oxfam model a reality, with new structures to support its delivery becoming operational. As

Oxfam GB, we:

- have transferred Oxfam GB staff and assets to management by: Oxfam Novib (Netherlands) in Cambodia, Vietnam, Niger and Nigeria; and by Oxfam Intermón (Spain) in Honduras, Bolivia and Guatemala;

- began the transition from lower priority countries to focus our discretionary programme investments in 35 countries where we feel we can achieve the greatest impact on poverty and injustice, reducing our investments in lower priority countries;

- completed the closure of three Oxfam GB regional centres in Latin America and the Caribbean, Southern Africa and Asia. Oxfam GB regional centres covering the Middle East and North Africa and West Africa were due to close at the end of June 2017. The Oxfam GB regional centre for the Horn, East and Central Africa was due to close at the end of July 2017 ;

- collaborated with Oxfam's newly established Global Humanitarian Team, which successfully joined up work across Oxfam's affiliates, to enable Oxfam to respond better to these complex emergencies.

Apart from transforming how Oxfam GB operates as an organization internationally, its centrally (UK-managed) operations and supply chains have not changed significantly. We therefore direct readers to pages 13-22 of last year's Modern Slavery Statement. Updated figures on staff workers and procurement spend are provided below.

For more detailed information on how and where we work and our governance structure, please see our Annual Report and Accounts.

\section{OXFAM GB'S STAFF AND CONTINGENT (CONTRACT) WORKERS}

Oxfam GB's headcount as of 1 April 2017 was: overall 4,924; UK 2,105; overseas 2,819 (see figure 3).

The number of contingent workers hired during 2016/17 in the UK was 106. This does not include workers from an agency with £6k spend that was recently identified. We will include them in next year's report. From our understanding, we do not hire contingent workers overseas. However, we are conducting an analysis during 2017/18 to confirm this. ${ }^{10}$ 
Figure 3: Total Oxfam GB staff and contingent workers on 1 April 2017

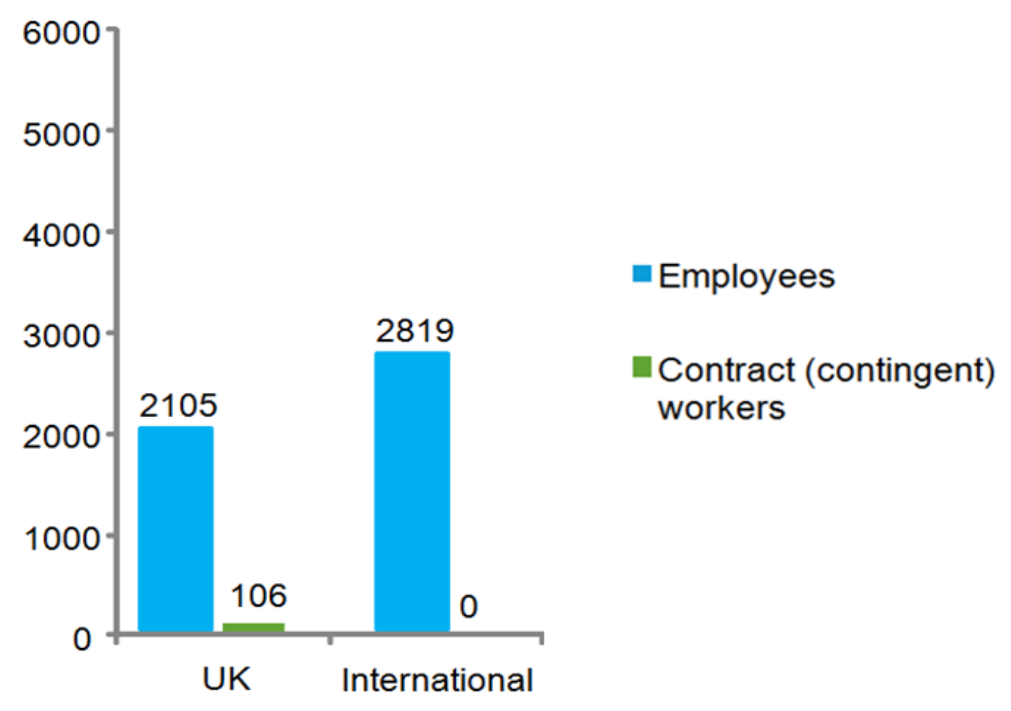

In the UK, we apply three categories to contingent workers as outlined in Table 8.

Table 8: Oxfam GB contingent workers in the UK

\begin{tabular}{|l|l|}
\hline $\begin{array}{l}\text { Category and number of } \\
\text { workers in financial year } \\
\mathbf{2 0 1 6 / 1 7}\end{array}$ & Current processes \\
\hline $\begin{array}{l}\text { 1. Specialist contractors } \\
\text { and senior management } \\
\text { positions: } \\
\text { 43 workers }\end{array}$ & $\begin{array}{l}\text { Workers are generally contracted on their own terms } \\
\text { (independent contracts, via limited companies or umbrella } \\
\text { company contracts) and are paid according to market rates, with } \\
\text { contracts being flexible for the duration of the assignment. } \\
\text { Minimum day rates are set in line with the market. } \\
\text { Hired through Crown Commercial Service (CCS)'s Contingent } \\
\text { Labour ONE (CL1) framework. }\end{array}$ \\
\hline $\begin{array}{l}\text { 2. Agency workers for } \\
\text { admin and clerical roles: }\end{array}$ & $\begin{array}{l}\text { We have a rate card for each role agreed in advance with the } \\
\text { agency, which ensures that all temporary workers are given pay } \\
\text { parity from day one. Agency workers are entitled to holidays } \\
\text { from day one on an unpaid basis and we offer paid leave on a } \\
\text { parity basis from week 13 of an assignment. } \\
\text { Hired through CCS's CL1 framework. }\end{array}$ \\
\hline $\begin{array}{l}\text { 3. Agency workers for } \\
\text { drivers, operations and } \\
\text { warehouse staff: } \\
\text { 44 }\end{array}$ & $\begin{array}{l}\text { Our process for engaging these types of worker is devolved to } \\
\text { commercial teams in the locations using the services. The } \\
\text { Procurement Team had an open vacancy for a large part of the } \\
\text { year and was not able to address the required improvements to } \\
\text { these processes. This vacancy has now been filled and we are } \\
\text { putting in place an improved due diligence process which will be } \\
\text { in effect within the next year. }\end{array}$ \\
\hline
\end{tabular}


For all three categories, we can confirm that: ${ }^{12}$

- Oxfam GB agency contracts in the UK do not include any form of accommodation or service packages, such as transportation;

- Contracts state that overtime is on a voluntary basis only;

- Contracts do not allow for fines to be imposed on workers;

- Passports are not retained but copied;

- Workers are not charged a finder's fee.

We can also confirm the following for Categories 1 and 2:

- The agencies are required to assure their own position on modern slavery independently, as they exceed the $£ 36 \mathrm{~m}$ annual turnover;

- Information is provided about workers' rights in a language that they understand.

While our HR Team is confident that we do not hire agency staff for our country programmes, it was agreed last year that we needed to introduce a mechanism to report on and confirm this. We worked with our Global Legal group to create a set of questions for our country programmes to report on, to confirm whether they hire contingent labour through agencies and if checks have been put in place to confirm that the agencies do not retain original passports, charge staff a finder's fee, or have any other mandatory deductions (other than legally required ones).

As our relationship with country programmes has changed over the past year (see the first part of section 3 for significant structural changes), it has been agreed that through the Global Legality Survey, Oxfam International will be able to include the questions on contingent labour hired by Oxfam in its annual reporting for all country offices, regardless of whether the staff are hired by Oxfam GB or another affiliate. This broadens the reporting scope from the 45 countries where Oxfam GB has investments to all 70 countries where the confederation works.

\section{OXFAM GB'S SUPPLY CHAINS}

Our supply chains have not changed significantly from last year's Modern Slavery Statement. We have prioritized UK-managed procurement as an area of immediate focus because:

a) it is where we have the most consolidated spend and leverage. Our UK-based procurement teams spend approximately $£ 55 \mathrm{~m}$ compared with $£ 75 \mathrm{~m}$ through 51 country programme offices (that often operate in fragile markets with weak legal infrastructure);

b) our International Division is in the middle of a major change process which includes changing executive power in some cases. We are taking some steps, but have had to delay most aspects of this work. 
Table 9: Oxfam GB's procurement structure and spend 2016/17

\begin{tabular}{|c|c|c|c|c|c|c|}
\hline $\begin{array}{l}\text { Procurement } \\
\text { category }\end{array}$ & $\begin{array}{l}\text { Managed } \\
\text { from }\end{array}$ & $\begin{array}{l}\text { Value of } \\
\text { spend }\end{array}$ & $\begin{array}{l}\text { Approx. } \\
\text { number of } \\
\text { suppliers }\end{array}$ & Purpose & Categories & $\begin{array}{l}\text { Key } \\
\text { sourcing } \\
\text { countries }\end{array}$ \\
\hline $\begin{array}{l}1 . \\
\text { Central } \\
\text { Procurement }\end{array}$ & UK & $£ 47 m$ & 2,675 & $\begin{array}{l}\text { To responsibly } \\
\text { source and } \\
\text { procure the } \\
\text { goods and } \\
\text { services } \\
\text { Oxfam GB } \\
\text { needs to } \\
\text { enable it to } \\
\text { deliver its } \\
\text { mission. }\end{array}$ & $\begin{array}{l}\text { Facilities, } \\
\text { logistics, IT, } \\
\text { marketing, } \\
\text { fundraising, HR, } \\
\text { finance and } \\
\text { travel }\end{array}$ & UK, China \\
\hline $\begin{array}{l}2 . \\
\text { New Products }\end{array}$ & UK & $£ 4 \mathrm{~m}$ & 73 & $\begin{array}{l}\text { Retail new } \\
\text { products sold } \\
\text { in Oxfam } \\
\text { shops to raise } \\
\text { unrestricted } \\
\text { funds. }\end{array}$ & $\begin{array}{l}\text { Food, everyday } \\
\text { essentials, } \\
\text { cards, } \\
\text { Christmas } \\
\text { ranges; } 50 \\
\text { percent of our } \\
\text { suppliers are } \\
\text { Fair Trade }\end{array}$ & $\begin{array}{l}\text { UK, India, } \\
\text { China }\end{array}$ \\
\hline $\begin{array}{l}3 . \\
\text { Humanitarian } \\
31 \\
\text { emergencies } \\
\text { in 2015/16; } \\
\text { Oxfam GB } \\
\text { reached } 9 \\
\text { million people }\end{array}$ & UK & $£ 4 m$ & 74 & $\begin{array}{l}\text { By providing } \\
\text { equipment } \\
\text { from the } \\
\text { Equipment } \\
\text { Catalogue } \\
\text { through Oxfam } \\
\text { GB's } \\
\text { Humanitarian } \\
\text { Procurement } \\
\text { Centre (HPC) } \\
\text { to not only } \\
\text { Oxfam GB and } \\
\text { its affiliates but } \\
\text { also other } \\
\text { NGOs, } \\
\text { including } \\
\text { UNHCR and } \\
\text { IOM. }\end{array}$ & $\begin{array}{l}\text { Water and } \\
\text { sanitation, } \\
\text { health and } \\
\text { hygiene, shelter, } \\
\text { vehicles, } \\
\text { communications } \\
\text { equipment, held } \\
\text { at the Oxfam } \\
\text { Supply Centre in } \\
\text { Bicester, } \\
\text { Oxfordshire }\end{array}$ & $\begin{array}{l}\text { Yemen, } \\
\text { South } \\
\text { Sudan, } \\
\text { Nepal, } \\
\text { Ethiopia, } \\
\text { Democratic } \\
\text { Republic of } \\
\text { Congo }\end{array}$ \\
\hline $\begin{array}{l}\text { 4. International } \\
\text { Programmes }\end{array}$ & $\begin{array}{l}51 \\
\text { developing } \\
\text { countries }\end{array}$ & $£ 75 m$ & $\begin{array}{r}15000 \\
\text { (est.) }\end{array}$ & $\begin{array}{l}\text { To support } \\
\text { Oxfam's } \\
\text { development } \\
\text { work on the } \\
\text { ground }\end{array}$ & $\begin{array}{l}\text { Direct, e.g. } \\
\text { office } \\
\text { equipment, fuel, } \\
\text { chickens. } \\
\text { Indirect e.g. } \\
\text { utilities, legal } \\
\text { advice. }\end{array}$ & $\begin{array}{l}\text { All the } \\
\text { countries in } \\
\text { which Oxfam } \\
\text { works }\end{array}$ \\
\hline Global total & & $£ 131.61 \mathrm{~m}$ & & & & \\
\hline
\end{tabular}




\section{OXFAM GB'S POLICIES, DUE DILIGENCE PROCESSES, RISK ASSESSMENTS, ACTION TAKEN AND TRAINING}

\section{POLICIES}

Oxfam GB has a commitment to write a new policy by March 2018, which will be informed by best practice. Meanwhile, we work to the policies outlined in Oxfam GB's Modern Slavery Statement for 2015/16, see pages 23-25.

\section{DUE DILIGENCE}

We are aware that our commitment to develop a new Due Diligence Framework is delayed. This is due to a number of reasons.

1. We prioritized putting in place appropriate cross-organizational governance and accountability frameworks. As mentioned earlier, this takes time but is fundamental to addressing modern slavery across the organization.

2. We have worked with others to drive forward a collaborative approach to credible and effective risk assessment mechanisms. which takes time; and

3. There was a delay in recruiting a new post to work on the revision of the Due Diligence Framework.

While we are in the process of revising the Due Diligence Framework and developing our Modern Slavery Strategy (see table 3 for updates), we continue to work to the frameworks that were included in last year's statement (pp. 26-43) to meet our supplierspecific commitments and have made a few small adjustments to our assessment process.

- In our retail supplier questionnaire, we have linked modern slavery to key questions relating to pay, hours and the right to work. We also include a much stronger section on freedom of association, to enable a better understanding of the supplier's approach to worker representation and workers' ability to access human rights in the workplace.

- In our central procurement supplier questionnaire, we now ask whether the supplier publishes a modern slavery statement and request a link to their statement.

\section{DISCLOSURE OF ANY IDENTIFIED INSTANCES OF MODERN SLAVERY AND THE RESULTS OF ANY CORRECTIVE ACTION PLANS}

The limitations in our current approach do not yet enable us to say unequivocally that there are no such instances occurring. What we can say is that the awareness we have built through our investment in training and governance and the work we are putting into developing a better due diligence framework will place us in a stronger position to be confident in our report findings in the coming years. 


\section{REMEDY AND COMPENSATION PROVIDED FOR LABOUR RIGHTS ABUSES}

For Oxfam GB staff, the 'Dealing with Problems at Work' policy and guidelines provide a clear process for workers, unions and management to follow to ensure that appropriate investigation, hearings and remedial actions take place.

We do not have a formal mechanism in place for our supply chains, and we are in the process of seeking examples of good practice to inform our approach.

\section{COMPANY-LEVEL GRIEVANCE MECHANISMS}

We have a global grievance procedure for staff and managers, along with a whistleblowing mechanism and a confidential employee assistance programme. The Oxfam Joint Trade Union Shop (OJTUS) unions are available to support workers through the grievance process along with HR. The grievance guidelines are based on ACAS procedures and were reviewed recently in consultation with the unions.

Three formal grievances were recorded in the UK and closed during the reporting period. The grievance allegations included unfair treatment, victimisation, bullying and discrimination. One was partially upheld with mediation offered, one was followed up with conciliation via ACAS and one was not upheld.

We do not have a mechanism for recording grievances at a country level. Given the level of change that is underway at a country level (see section 3 ) this cannot currently be prioritized.

We recognize that grievance mechanisms are often not appropriate for complex cases of abuse, human trafficking or sexual exploitation. We therefore have a dedicated team in place with expert knowledge and skills to address this and we remain committed to transparency on allegations of sexual exploitation and abuse perpetrated by our staff and partners.

In 2016/17 we saw a small increase in the number of reported incidents from 76 to 87 . Thirty-three allegations were investigated, one allegation is pending investigation and the remaining 53 incidents required referral to statutory services (including Police, Social Services and the Disclosure and Barring Service), related to vetting or reference requests or required other forms of signposting to other specialist support services. A small number of incidents (four) were not investigated at the request of the complainant, but we addressed them in other ways.

Thirty-four of the reported incidents were complaints which required internal investigation by the Safeguarding Team; seventy-four percent of these complaints were fully upheld and resulted in disciplinary action being taken at the time of reporting. One case is currently pending investigation. In nine cases (7 percent of reported allegations) we found insufficient evidence to uphold any part of the allegation, and in these instances other actions were taken to reflect the learning of the organization. All other incidents raised either required investigation by external agencies; had already been upheld by the evidence provided at the point of reporting; or required some other form of response (including providing support to staff and volunteers who disclosed being the victim of violence in the home). Of the total of 87 reported incidents in 2016/17, 52 were 
received from the Trading Division, 10 were received from other UK divisions and 25 from the International Division.

Under-reporting is recognized within the sector as the major barrier to tackling sexual exploitation and abuse in delivering humanitarian and development programmes. By establishing a dedicated safeguarding team, we have raised the visibility of our policies on Protection from Sexual Exploitation and Abuse and Child and Vulnerable Adult Protection and their reporting procedures. We believe that the overall increases in the number of allegations that we have seen in recent years show that we are improving awareness of this important issue and giving victims more confidence to report incidents. Please see the case study below for more information on our approach to safeguarding.

\section{CASE STUDY 2: OUR SAFEGUARDING WORK}

Oxfam GB's Safeguarding Team was set up in 2012 to respond to and prevent incidents of sexual exploitation and sexual abuse (including beneficiary, child and vulnerable adult abuse). It aims to create an operating environment that is free from sexual violence and abuse of power. The team is an independent function staffed by specialists who work from a survivor-led perspective to respond to concerns and complaints raised against our representatives, or by our staff who experience sexual violence during the course of duty.

Underlying the whole of the approach must be a recognition that there is a duty to act, and in doing so a need for open-mindedness. Getting this sort of approach right is about living our values, even when it means accepting what can be difficult truths about ourselves. To do that, there must be acceptance of the problem.

Across the sector and beyond, too often complainants can be blamed for the violence they have experienced and can be ignored, silenced, demeaned, sacked and/or blacklisted. Responding to sexual harassment and assault requires preparedness and expertise. ${ }^{13}$

'If you aren't looking for this problem you won't see it, and when you do see it you must have a process to guide what happens next.'

Hannah Clare, Oxfam GB Head of Safeguarding

A key function of the Safeguarding Team is to build the confidence of individuals and other stakeholders in the structures that we have designed to respond to this problem. For example, we know that people generally prefer to report to people they know and trust, rather than reporting anonymously through email or phone. The Safeguarding Team therefore identified the need to train staff (often with a human resource or specialized gender background whom staff already knew) as safeguarding focal points in each of our different locations. Since 2012 we have regularly trained regional and country-level focal points, who operate as a network of approximately 80 at any one time. The focal points have become the face of the safeguarding complaints mechanism. The Safeguarding Team works hard to maintain the relationship and a clear line of communication with this group The Safeguarding Team found that many individuals also prefer speaking to investigators from outside of their location, because they may feel intimidated within their own team, or they do not want to speak to someone that they see on a daily basis about the investigation. ${ }^{14}$

Since the current approach was put into place in 2012, the Safeguarding Team has seen an increase each year in the number and diversity of issues being raised. The 
team now investigates 93-95 percent of cases reported to them. A small number of incidents have not been investigated at the request of the complainant, but we addressed them in other ways. The team is also seeing fewer cases of survivors not following through with the investigation process or not going forward because they fear their perpetrators or undesirable outcomes.

The Safeguarding Team's investigation process was designed using best practices for protection from sexual exploitation and sexual abuse (PSEA), drawing from the work of the InterAgency Standing Committee Task Force on the 'protection from sexual exploitation and sexual abuse (PSEA) by our own staff'.

'These policies need to recognize that unequal power relationships are at the heart of abusive and exploitative behaviours.'

Hannah Clare, Oxfam GB Head of Safeguarding

It is understood that introducing staff with specialist listening skills, familiarity with the dynamics and patterns of abuse and an understanding of the enormous impact it has on individuals and communities has helped to inspire the trust which has led to this trend. It takes time to build trust, and the team will dedicate time to answering questions and exploring people's fears around disclosing detail. We learned that an approach which relies on non-specialists to carry out such sensitive work led to fewer complainants having the confidence to participate in investigations or any sort of formal response processes. Note the increase in allegations from 2012 when regional focal points were established. 
Figure 4: Increase of reporting of allegations once regional focal points are created

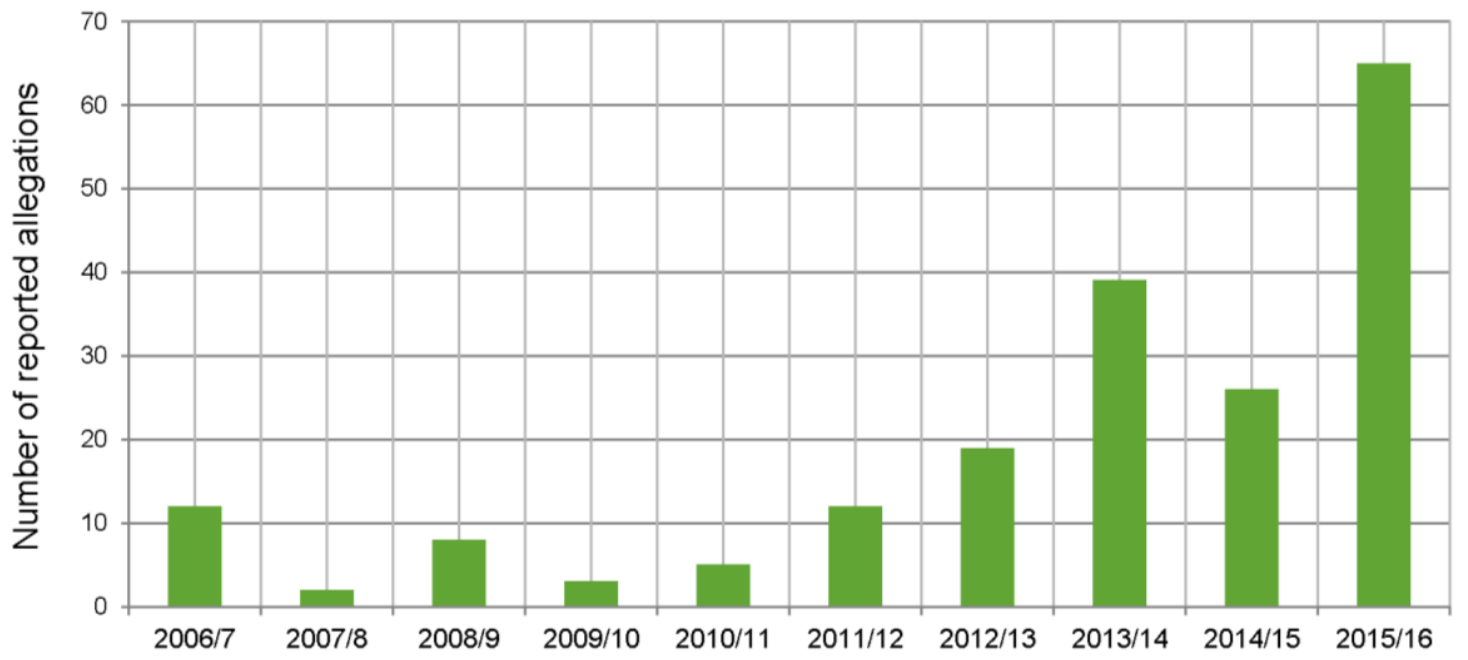

\begin{tabular}{|c|c|c|c|c|c|c|c|c|}
\hline & & & 1 & & & & & \\
\hline $\begin{array}{l}2002 \\
\text { West Africa } \\
\text { food for } \\
\text { sex } \\
\text { scandal }\end{array}$ & $\begin{array}{l}2003 \\
\text { First } \\
\text { PSEA } \\
\text { staff } \\
\text { member }\end{array}$ & $\begin{array}{l}2006 \\
\text { Liberia } \\
\text { sex for } \\
\text { soap } \\
\text { scandal }\end{array}$ & $\begin{array}{l}2007 \\
\text { Trained } 20 \\
\text { internal } \\
\text { investigators }\end{array}$ & $\begin{array}{l}2008 / 09 \\
\text { PSEA } \\
\text { remit } \\
\text { removed } \\
\text { to } \\
\text { corporate } \\
\text { HR }\end{array}$ & $\begin{array}{l}2011 / 12 \\
\text { PSEA } \\
\text { changed to } \\
\text { Safeguarding }\end{array}$ & $\begin{array}{l}2012 / 13 \\
\text { Regional } \\
\text { focal } \\
\text { points }\end{array}$ & $\begin{array}{l}2013 / 14 \\
\text { Country } \\
\text { focal } \\
\text { points }\end{array}$ & $\begin{array}{l}2014 / 15 \\
\text { Safeguarding } \\
\text { team } \\
\text { unstaffed for } 5 \\
\text { months }\end{array}$ \\
\hline
\end{tabular}

An important part of becoming more accessible to survivors and complainants is being able to demonstrate that appropriate and strong action is taken against staff found to have carried out abusive behaviours. One of the best ways to facilitate this outcome is to carry out high quality investigations which take guidance from comprehensive and meaningful policies. These policies need to recognize that unequal power relationships are at the heart of abusive and exploitative behaviours, and that such behaviours form a wide spectrum of sexual violence; critically, harsh sanctions must be mandated for perpetrators, and all managers need to understand their own role in creating a safe working environment for all. In order to achieve this, we need investigators who are rigorous, familiar with the subject matter and who are also trained to support leaders through the multiple and complex risks associated with serious incidents.

Fears around confidentiality and of not being believed are among the most commonly cited barriers to reporting experiences of sexual violence, whether in the context of Oxfam or in general. A crucial part of this approach means investing in a network of trained focal points and delivering specialist training and awareness-raising to all stakeholders. Oxfam GB includes clear messages that the organization is aware that violence like this does happen and also that survivors will be believed and taken seriously if they choose to make a disclosure. Safeguarding Focal Points provide a face and a sense of familiarity to the complaints process and have been widely recognized as one of the most important elements to the success of this work. In short, if you aren't looking for this problem you won't see it, and when you do see it, you must have a process to guide what happens next.

Finally, organizations must recognize the true cost of building trust and then getting any part of the ensuing response wrong. For some survivors this could mean being exposed to violence, losing the capacity to earn or having their reputation and support network destroyed. Avoiding outcomes like these has to drive every part of our approach, and in order to do that we have had to invest in mechanisms and processes for capturing and using learning all of the time. It continues to pay off, but will always require investment. 


\section{TRAINING AND ITS IMPACT}

In 2016 Oxfam GB's central (UK) procurement, retail buying teams and key retail suppliers attended a half day training session on our corporate responsibility programme, in which we covered the following issues regarding modern slavery:

- Forms of modern slavery

- Sourcing countries where modern slavery is more prevalent

- Forms of modern slavery that may exist in our supply chains

- Why modern slavery is difficult to detect

- Oxfam's approach to addressing modern slavery

- How modern slavery links to key issues of wages and the right to freedom of association

- Overview of the broader issues of inequality and labour rights

We did short surveys prior to and after training to measure the impact of the training (see the results in table 10). Unfortunately the retail buying team's pre-training surveys were misplaced, impacting our analysis of this group. 
Table 10: Pre- and post-training analysis

\begin{tabular}{|c|c|c|c|c|}
\hline \multicolumn{2}{|c|}{$\begin{array}{l}\text { Survey analysis pre- and post-training on } \\
\text { modern slavery with our staff and suppliers }\end{array}$} & \multicolumn{2}{|c|}{ Average scores out of 5} & \multirow{3}{*}{$\begin{array}{l}\begin{array}{l}\% \\
\text { Increase } \\
\text { average }\end{array} \\
18 \% \\
\end{array}$} \\
\hline & & \multirow{2}{*}{$\begin{array}{r}\text { Pre-training } \\
\\
3.40\end{array}$} & \multirow{2}{*}{$\begin{array}{l}\text { Post- } \\
\text { training } \\
\\
\\
\\
\quad 4.00\end{array}$} & \\
\hline \multirow{3}{*}{ What modern slavery is } & $\begin{array}{l}\text { Central } \\
\text { procurement }\end{array}$ & & & \\
\hline & Retail buyers & & 4.2 & \\
\hline & Suppliers & 3.7 & 4.3 & $16 \%$ \\
\hline \multirow{3}{*}{$\begin{array}{l}\text { What types of industries } \\
\text { and countries it may be } \\
\text { found in }\end{array}$} & $\begin{array}{l}\text { Central } \\
\text { procurement }\end{array}$ & 3.3 & 3.9 & $21 \%$ \\
\hline & Retail buyers & & 4.0 & \\
\hline & Suppliers & 3.5 & 4.1 & $17 \%$ \\
\hline \multirow{3}{*}{$\begin{array}{l}\text { What steps Oxfam is } \\
\text { taking to address } \\
\text { modern slavery }\end{array}$} & $\begin{array}{l}\text { Central } \\
\text { procurement }\end{array}$ & 2.9 & 3.3 & $15 \%$ \\
\hline & Retail buyers & & 3.6 & \\
\hline & Suppliers & 3.5 & 4.1 & $17 \%$ \\
\hline \multirow{3}{*}{$\begin{array}{l}\text { How relevant modern } \\
\text { slavery is to your role }\end{array}$} & $\begin{array}{l}\text { Central } \\
\text { procurement }\end{array}$ & 3.0 & 3.5 & $17 \%$ \\
\hline & Retail buyers & & 4.2 & \\
\hline & Suppliers & 2.6 & 3.9 & $50 \%$ \\
\hline \multirow{3}{*}{$\begin{array}{l}\text { Why modern slavery is } \\
\text { difficult to detect }\end{array}$} & $\begin{array}{l}\text { Central } \\
\text { procurement }\end{array}$ & 3.1 & 4.3 & $38 \%$ \\
\hline & Retail buyers & & 4.4 & \\
\hline & Suppliers & 2.6 & 3.9 & $50 \%$ \\
\hline
\end{tabular}

Overall, the training had a positive impact on the participants' knowledge, awareness and confidence.

A high increase in knowledge about 'why is MS difficult to detect' and 'how relevant MS is to your role', where suppliers also noted a larger increase in average scores (50 percent), was shown with the central procurement and supplier participants.

The training also had a positive impact on motivation to take action on modern slavery; however participants did not feel more confident in finding ways to address it in their own organization and supply chains. We are using this result to inform our next steps on training and support materials.

Since the training, we have seen increased understanding of the importance of the issue from our internal teams and suppliers with a request for increased support and tools. These, along with other impact measures will be developed over the next year. 


\section{INSIGHTS AND SIGNPOSTS}

In this section we outline some learning and refer to resources we have found useful both for our advocacy and our work to prevent modern slavery in our own operations and supply chains.

\section{A BUZZ OF ACTIVITY}

Since the Modern Slavery Act entered into force in October 2015, there has been a step change in interest from senior management and investors. The Transparency in Supply Chain (TISC) requirement of the Act requires CEOs of companies with a turnover of more than $£ 36 \mathrm{~m}$ to sign an annual statement about the action their company has taken to mitigate slavery and human trafficking in their operations and supply chains. This means that CEOs are now directly involved with a topic that few knew anything about previously. There has been a buzz of activity as companies learn about the issues, make judgements about the impact of what they currently do and take decisions about what actions they will take in the future and how they will report on them.

New guidance published by Ethical Trading Initiative, Institute of Human Rights and Business \& Hogan Lovells, Corporate Responsibility (CORE) coalition ${ }^{15}$ and an antislavery charter published by Anti-Slavery Internationa $\left.\right|^{16}$ will help companies navigate this terrain.

A recent survey of retailer and brand senior managers found that 77 percent of companies think there is a likelihood of modern slavery occurring in their supply chains. This highlights that the compliance approach has not delivered and must be rethought. However, while in 2015 no companies thought that investors were a driver for company action on modern slavery, by 2016 that figure had jumped to 25 percent, so the need to find effective approaches is growing. ${ }^{17}$

We recognize that companies are still mainly driven by reputational risk, however, in most cases it remains unclear if or how company responses are integrated into core operations or corporate culture. To support companies to make these changes, we would like to see investors play a more active role in engaging investee companies to improve their mitigation and response to modern slavery, rather than react to media scandals and legal actions in ways that cause their share price to drop. In Oxfam's experience, it is critical that senior management are fully informed and have the skills and willingness to listen to 'bad news' about cases of exploitation reported upwards. It is each company's senior managers, board and investors who must lead the transformation of corporate culture required to move core operations beyond compliance.

Oxfam GB is working with ShareAction to support investors to engage more proactively with companies to disclose what they do to deliver decent work through their operations and supply chains, and that will enable the companies to run the business sustainably over the long term. The take-up has exceeded expectations and already 79 institutional investors with nearly $\$ 8$ trillion of assets under management have signed up. ${ }^{18}$ That is more than three times the UK's GDP. 


\section{REGULATION}

There is a trend towards increased regulation. Based on a survey by Morgan Stanley, 62 percent of the large listed companies around the world will be subject to the Modern Slavery Act in the UK, the California Transparency in Supply Chains Act or the Business Supply Chain Transparency on Trafficking and Slavery Act in the US. ${ }^{19}$

The EU Non-Financial Reporting Directive 2014/95/EU entered into force in the UK in December 2016. It requires companies of more than 500 employees to report on a number of social and environmental matters, including their due diligence process and respect for human rights. Over the last year, Holland ${ }^{20}$ and France ${ }^{21}$ passed legislation that raises this bar and other European countries have similar legislation in the pipeline.

Since the end of this reporting period, in July 2017 Baroness Young of Hornsey proposed two additions to the UK Modern Slavery Act. One calls for the publication of a full list of companies that should be reporting under the Act. The other proposes that companies that have not published a statement should be excluded from bidding for public procurement contracts. ${ }^{22}$

In May 2017 the $\mathrm{G} 20^{23}$ announced that they would take 'immediate and effective measures to eliminate child labour by 2025 , forced labour, human trafficking and all forms of modern slavery'. The G20 also reconfirmed their commitment to the UN Guiding Principles on Business and Human Rights, the ILO Declaration on multinational enterprises and social policy and the OECD Guidelines for Multinational Enterprises and its complaints mechanism. They committed to clearly communicating their expectations that businesses should carry out due diligence and be transparent about their global supply chains. They also said they would welcome industry-wide due diligence. ${ }^{24}$ These are ambitious commitments given that many member states are far from upholding even basic labour rights, ${ }^{25}$ but progress in this direction looks like it could be on the horizon and would be particularly welcome if governments stepped up their efforts to lead by example.

\section{STEPS TOWARDS TRANSFORMATION}

We want to see businesses and investors put their own houses in order and actively address systemic issues to eradicate modern slavery and deliver decent work. We want to see more collaborative efforts to achieve a transformation, so that markets will reward companies for doing the right thing.

In this changing landscape, we think it will be important for companies to ensure their staff are well versed in competition law, so that they are confident in taking the necessary steps to collaborate across each country and sector and make serious commitments to collective action to eradicate modern slavery. Fair Wear Foundation's Competition Law Dos and Don'ts may be useful in that regard. ${ }^{26}$ Robust supply chain transparency and traceability also provide an important foundation for effective collaboration. ${ }^{27}$

If a company cuts-and-runs from a supplier where modern slavery is found, it makes the situation worse. ${ }^{28}$ Therefore a policy of zero tolerance towards forced labour as a whole can be problematic. However we do want to see companies following ETI guidance and adopting a policy of 'zero tolerance to inaction' on modern slavery. This would include ensuring that no worker pays for a job, ${ }^{29}$ together with collective industry-wide action to eradicate poor practice, cover ups and false declarations. ${ }^{30}$ 
To go beyond compliance, companies should provide commercial incentives to suppliers that proactively uphold labour rights, carry out robust human rights due diligence, ${ }^{31}$ and learn how to listen to the workers who produce the goods and services they buy and sell. To be able to identify and remedy modern slavery, there is a need to draw on the lessons already learned from survivors of human trafficking and sexual exploitation in the workplace, and what has worked to respond effectively to their needs and wishes to date.

When we apply a modern slavery lens to the work we do to address in-work poverty in global supply chains, it becomes even clearer that companies must make urgent progress on delivering decent wages and the right to freedom of association and collective bargaining. There is so much more that can be done to reduce the vulnerability of women ${ }^{32}$ and men. So we must prioritize taking these actions now; alongside learning how we can improve our mitigation and response. For example, Oxfam is working with the Malawi Tea 2020 coalition to support their ambition to pay a living wage to the plantation workers that pick their tea by $2020 .{ }^{33}$

We will need to bring into the work of investors and companies in society the lens of how power, risk and value are shared through their operations and supply chains if we are to have a chance of eradicating modern slavery. 


\section{ACKNOWLEDGEMENTS}

This statement was written by Alex Cole-Hamilton, Head of Corporate Responsibility, and Beck Wallace, Ethical Trade Advisor, Oxfam GB. We acknowledge invaluable comments from Klara Skrivankova, Anti-Slavery International. We would also like to thank Oxfam GB staff members Martijn Blansjaar, Sophie Brill, Hannah Claire, Anna Coryndon, Nikki Glover, Caroline Gow, Adrian Hook, Phil Perkins, Nick Pialek, Jon Slater, Michael Taylor Sarah Keogh, and Rachel Wilshaw.

\section{Front cover photos, clockwise from top left:}

The Oxfam shop at Cowley Road, Oxford, 2016. Photo: Rachel Manns/Oxfam

Beadwork: A woman in Bidibidi refugee settlement in Northern Uganda, the largest refugee settlement in the world, making jewellery to sell at the local market, 2017. Photo: Kieran Doherty/Oxfam

Sarah is the chairperson of a handcrafts group in Bidibidi refugee settlement. With the help of Oxfam and partner CEFORD the group was established to enable women to earn an income and socialize. Their products are sold at the local market. Photo: Kieran Doherty/Oxfam (2017)

Filling jerry cans with water at Imvepi refugee settlement, Uganda, 2017. Photo: Kieran Doherty/Oxfam 
1 ILO (2016) Forced Labour, Human Trafficking and Slavery. http://www.ilo.org/global/topics/forcedlabour/lang--en/index.htm. In November 2017 we expect to have new estimates of modern slavery figures: http://www.ilo.org/global/topics/forcedlabour/news/WCMS_547304/lang--en/index.htm

2 ILO (2014). Profits and Poverty: The Economics of Forced Labour. http://www.ilo.org/global/topics/forcedlabour/publications/WCMS_243027/lang--en/index.htm

3 https://www.cips.org/supply-management/news/2017/june/prosecutions-under-the-modern-slavery-actmore-that-quadruple/

4 Although they were convicted for trafficking under the Asylum and Immiaration (Treatment of Claimants, etc.) Act 2004, (not the Modern Slavery Act) see: http://www.thelawpages.com/criminaloffence/Trafficking-people-for-labour-exploitation-644-23.law

5 http://www.independent.co.uk/news/business/news/sports-direct-mike-ashley-worker-conditionsminimum-wage-ian-wright-investigation-a7149971.html

6 Oxfam GB (2016). Oxfam GB Statement on Modern Slavery: For the financial year 2015/16. http://policy-practice.oxfam.org.uk/publications/oxfam-gb-statement-on-modern-slavery-for-thefinancial-year-201516-620092

7 Head of Procurement, Head of Trading Corporate Partnerships, Head of New Products, Head of Supply and Logistics and their teams.

8 Drivers and warehouse contract workers who are currently not managed through the centralized framework detailed in our last statement.

9 Rachel Willshaw (August 2017). Making 'people are our greatest asset' ring true. Oxfam blog. https://views-voices.oxfam.org.uk/general/2017/08/making-people-are-our-greatest-asset-ring-true/

10 We are not aware of any overseas staff sourced through agencies, however we are conducting a risk assessment across the programmes to confirm this is the case.

11 See note 8 .

12 See note 8.

13 Feinstein International Center (May2017). Stop the Sexual Assault Against Humanitarian and Development Aid Workers. http://fic.tufts.edu/publication-item/stop-the-sexual-assault-againsthumanitarian-and-development-aid-workers/ pp52-55.

14 Ibid.

15 Ethical Trading Initiative: http://www.ethicaltrade.org/resources/base-code-guidance-modern-slavery; Institute of Human Rights and Business \& Hogan Lovells, (Oct 2016),

https://www.ihrb.org/uploads/reports/IHRB\%2C_Corporate_Liability_for_Forced_Labour_and_Human_ Trafficking\%2C_Oct._2016.pdf; and CORE: http://corporate-responsibility.org/mini-briefings-modernslavery/.

16 https://www.antislavery.org/anti-slavery-charter/

17 Ethical Trading Initiative and Hult International Business School, (Nov 2016) https://www.ashridge.org.uk/getmedia/bea3966b-0657-402f-81eb-c203b95759ad/CorporateLeadership-on-Modern-Slavery-Full-Report-and-Case-Studies-2016.pdf, p25

18 ShareAction. Workforce Disclosure Initiative. https://shareaction.org/wdi/

19 Morgan Stanley Capital International (MSCI) (2015). Slaving Away in Hiding. All Country World Index covering 23 developed and 24 developing countries.

20 The Dutch parliament passed a Mandatory Due Diligence Child Labour Law in February 2017 which will enter into force 1 January 2020 and requires Dutch companies and companies that sell to consumers in the Netherlands to carry out human rights due diligence. https://www.linkedin.com/pulse/due-diligence-child-labour-new-law-netherlands-annelien-van-meer

21 A French Corporate Duty of Vigilance law was approved in March 2017 and will enter into force in 2018. It requires large French companies to state the measures they have taken to 'identify and prevent the occurrence of human rights and environmental risks resulting from their activities, the activities of companies they control and the activities of sub-contractors and suppliers on whom they have a significant influence'. Entreprises: devoir de vigilance des entreprises donneuses d'ordre http://www.assemblee-nationale.fr/14/dossiers/devoir_vigilance_entreprises_donneuses_ordre.asp

22 https://publications.parliament.uk/pa/bills/lbill/2017-2019/0057/18057.pdf 
23 The group of the world's seven most powerful industrialized countries (G7), the US, Japan, Germany, the UK, France, Italy and Canada, agreed the formation of the Group of 20 (G20) to respond to the global financial crisis in 1997-9.

The G20 comprises 19 countries: the European Union, plus representatives of the International Monetary Fund and the World Bank. Members are: Argentina, Australia, Brazil, Canada, China, France, Germany, India, Indonesia, Italy, Japan, Mexico, Russia, Saudi Arabia, South Africa, Korea, Turkey, United Kingdom, United States, European Union. Plus: International Monetary Fund, World Bank, International Monetary and Financial Committee (ex officio), Development Committee of the International Monetary Fund and World Bank (ex officio).

24 https://www.g20.org/gipfeldokumente/G20-leaders-declaration.pdf

25 ITUC. (2017). ITUC Global Rights Index. https://www.ituc-csi.org/ituc-global-rights-index-2017

26 https://www.fairwear.org/wp-content/uploads/2016/06/FWF-guidancecompetitionlawjuly15.pdf

27 Oxfam Australia (2016). Still In the Dark: Lifting the cloak on the global garment trade. https://www.oxfam.org.au/stillinthedark/

28 ETI (2017). Modern Slavery and Child Labour: It's all about choice. http://www.ethicaltrade.org/blog/modern-slavery-and-child-labour-its-all-about-choice

29 The International Labour Organization's Convention 181 on Private Employment Agencies states that recruiters should not charge any fees to workers http://www.ilo.org/dyn/normlex/en/f?p=NORMLEXPUB:12100:0::NO::P12100_INSTRUMENT_ID:3123 26

The Dhaka Principles state that no fees should be charged to workers http://www.dhaka-principles.org/

The global industry association's code of conduct, outlined by the International Confederation of Private Employment Agencies (Ciett) also prohibits members from charging any fees http://www.wecglobal.org/fileadmin/templates/ciett/docs/CIETT Code Conduct.pdf and http://www.ituc-csi.org/lMG/pdf/no_09_-_dhaka_principles_-_short_version_english.pdf

In May 2016 the Leadership Group for Responsible Recruitment committed to the Employer Pays Principle: https://www.ihrb.org/employerpays/leadership-group-for-responsible-recruitment

In Dec 2016 the Consumer Goods Forum included the principle that no worker should pay for a job in their priority principles for all retailer and manufacturer members

http://www.theconsumergoodsforum.com/consumer-goods-industry-sets-bar-in-fight-against-forcedlabour.

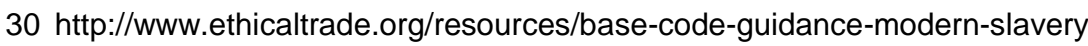

31 See: http://www.ohchr.org/Documents/Publications/GuidingPrinciplesBusinessHR_EN.pdf; http://mneguidelines.oecd.org/oecd-fao-guidance.pdf;

https://www.shiftproject.org/resources/publications/doing-business-with-respect-for-human-rights/ and http://www.ethicaltrade.org/resources/human-rights-due-diligence-framework

32 Companies should implement the UN Women's Empowerment Principles: http://www.weprinciples.org/ and address the factors that indicate women are most at risk of being left behind from economic empowerment:

multiple forms of discrimination,

lack effective representation in the work place,

inadequate earnings,

excessive overtime,

poor working conditions,

sexual harassment.

F. Rhodes (March 2017). An Economy that Works for Women: Achieving women's economic empowerments in an increasingly unequal world. Oxfam. https://www.oxfam.org/en/research/economyworks-women, p15

33 Malawi Tea 2020. http://www.malawitea2020.com/ 
This publication is copyright but the text may be used free of charge for the purposes of advocacy, campaigning, education, and research, provided that the source is acknowledged in full. The copyright holder requests that all such use be registered with them for impact assessment purposes. For copying in any other circumstances, or for re-use in other publications, or for translation or adaptation, permission must be secured and a fee may be charged. Email policyandpractice@oxfam.org.uk

The information in this publication is correct at the time of going to press.

Published by Oxfam GB under ISBN 978-1-78748-079-7 in September 2017. DOI: 10.21201/2017.0797 Oxfam GB, Oxfam House, John Smith Drive, Cowley, Oxford, OX4 2JY, UK. 


\section{An example of Oxfam's programme work to address modern slavery in Thailand}

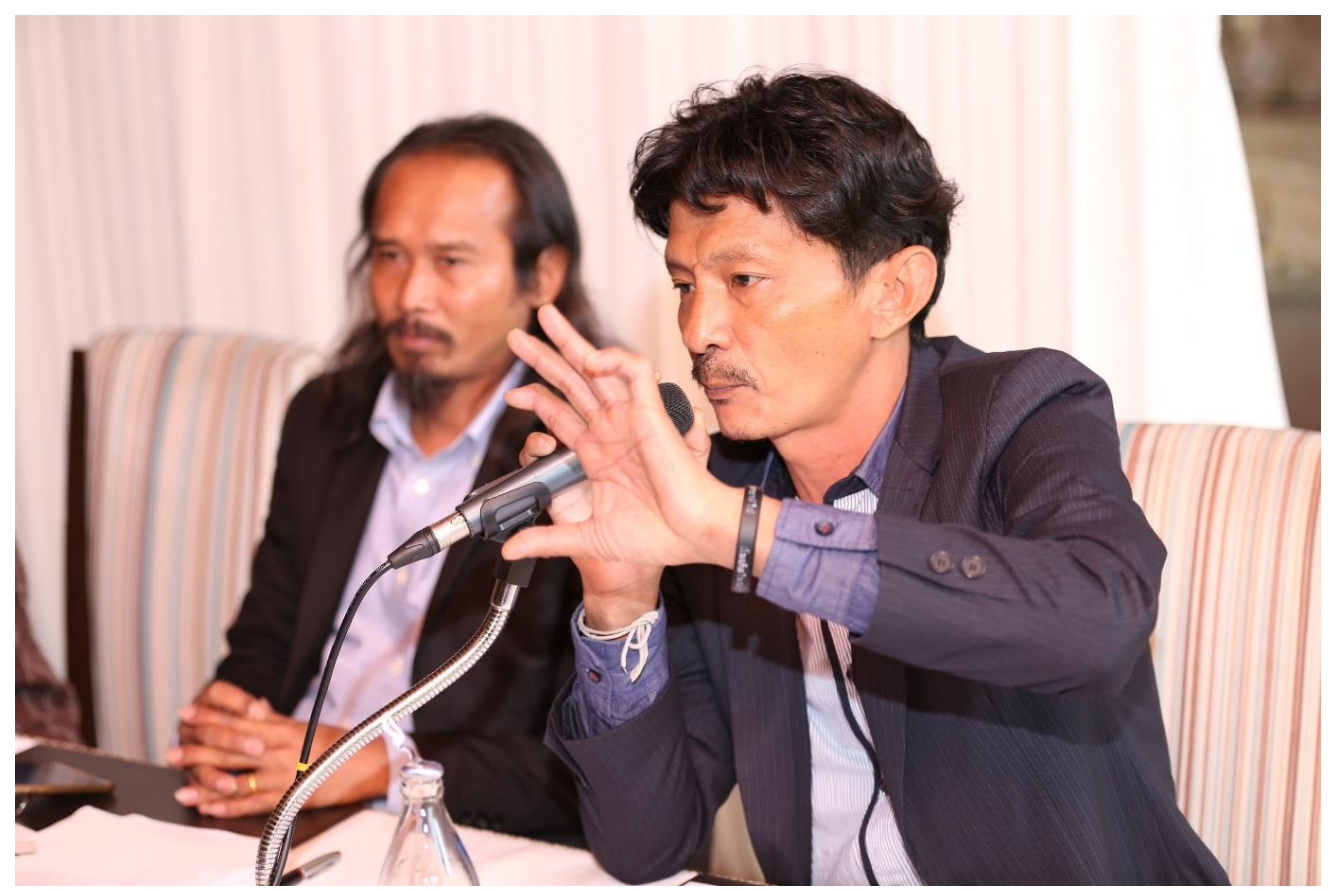

Photo: Oxfam

Samart Senasu (right), a survivor of modern slavery, tells his story at a Bangkok press conference in January 2017. Samart is a Thai worker who lost his job in 2009, met a stranger who drugged him, and was then trafficked onto a fishing vessel. There he was kept in modern slavery for six years, overworked and beaten, until he was rescued in Indonesia in 2015. Oxfam in Thailand helps people like Samart to get support through NGO partners such as Labour Rights Promotion Network (left). Oxfam convenes the Thailand Coalition on Sustainable and Ethical Seafood which brings together civil society actors to address egregious environmental and labour rights issues in the Thai fishery sector. Thailand remains on a 'Tier 2 Watchlist' of countries whose governments are not fully complying with the Trafficking Victims Protection Act, despite making significant efforts to do so.

\section{OXFAM}

Oxfam is an international confederation of 20 organizations networked together in more than 90 countries, as part of a global movement for change, to build a future free from the injustice of poverty. Please write to any of the agencies for further information, or visit www.oxfam.org 